\title{
Binding of glycoglycerolipid derived from membranes of Acholeplasma laidlawii PG8 and synthetic analogues to lymphoid cells
}

\author{
Saori Toujima, ${ }^{1}$ Koichi Kuwano, ${ }^{1}$ Ye Zhang, ${ }^{1}$ Naoyuki Fujimoto, ${ }^{1}$ \\ Masahiro Hirama, ${ }^{2}$ Tohru Oishi, ${ }^{2}$ Sumiko Fukuda, ${ }^{2}$ Yoko Nagumo, ${ }^{2}$ \\ Hiroto Imai, ${ }^{2}$ Tsukasa Kikuchi ${ }^{2}$ and Sumio Arai ${ }^{1}$
}

\begin{abstract}
1 Department of Bacteriology, Kurume University School of Medicine, 67 Asahi-machi, Kurume 830-0011, Japan

2 Department of Chemistry, Graduate School of Science, Tohoku University Aoba, Aramaki aza, Aoba$\mathrm{ku}$, Sendai 980-8578, Japan
\end{abstract}

Author for correspondence: Sumio Arai. Tel: +8194231 7548. Fax: +81942310343. e-mail: sumiyuku@mx2.tiki.ne.jp

Keywords: Acholeplasma laidlawii, adherence, glycoglycerolipids, lymphoid cells

\section{INTRODUCTION}

The first stage in many bacterial infections is adherence and formation of microcolonies on mucous membranes. Various components on the outer surface of bacteria, such as protein, polysaccharides and teichoic acid, are known to contribute to adherence (Espersen \& Clemmensen, 1982; van Houte 1983; Elleman et al., 1986; Courtney et al., 1986). However, $\beta$-lactam antibiotics, which inhibit cell wall synthesis, can induce the formation of L-form variants (Allan et al., 1993). Glycoglycerolipids are found not only in the cell membranes of mycoplasmas, but also in those of Grampositive and Gram-negative bacteria (Kates, 1990). Although there have been many investigations into the role of microbial glycoglycerolipids in the membrane physiology of prokaryotic cells (Shaw, 1970; Silvius et al., 1980; Boggs 1987), we have no knowledge of interactions of glycoglycerolipids with eukaryotic cells. It is

Abbreviation: GAGDG, 3-O-[2'-O-( $\alpha$-D-glucopyranosyl)-6'-O-acyl- $\alpha$-Dglucopyranosyl]-1,2-di-O-acyl-sn-glycerol. important in investigating the pathogenesis of bacteria lacking cell walls that such factors which may influence attachment to host cells be studied.

The aim of the work described in this paper was to examine the capacity of glycoglycerolipids isolated from the membranes of Acholeplasma laidlawii, and of chemically synthesized glycoglycerolipids, to bind to human lymphoid cells.

\section{METHODS}

Cells. Two human T-cell lines, MOLT-4 and HUT-78, a human B cell line, Raji, and a human monoblastic cell line, HL60, were maintained in exponential growth in RPMI1640 medium containing $10 \%$ foetal calf serum (FCS; Mitsubishi Chemical), $2 \mathrm{mM}$ L-glutamine, $100 \mu \mathrm{g}$ penicillin $\mathrm{G} \mathrm{ml}^{-1}$ and $100 \mu \mathrm{g}$ streptomycin $\mathrm{ml}^{-1}$ (RPMI/FCS). To exclude the possibility of mycoplasma infections in the cell cultures, these cell suspensions were inoculated onto Hayflick's mycoplasma agar medium once a week.

Peripheral mononuclear cells from healthy donors were isolated using Lymphoprep (Nycomed Pharma AS Diag- 
Table 1. Binding activity of fractions of $A$. laidlawii membrane extracts separated by silica-gel chromatography

MOLT- 4 cells $\left(2 \times 10^{5}\right)$ were incubated at $37^{\circ} \mathrm{C}$ for $4 \mathrm{~h}$ in the presence of a coverglass with $10 \mu \mathrm{g}$ of each fraction. Values shown are means \pm SD of five assays from one representative experiment.

\begin{tabular}{|lcc|}
\hline $\begin{array}{l}\mathrm{CHCl}_{3} / \mathrm{MeOH} \\
(\mathbf{4 0 0} \mathbf{~ m l})\end{array}$ & Recovery $(\%)^{*}$ & $\begin{array}{c}\mathbf{1 0}^{-4} \times \text { Number } \\
\text { of adherent cells } \\
\text { per coverglass }\end{array}$ \\
\hline $\mathrm{CHCl}_{3}$ & $19 \cdot 9$ & $0 \cdot 3 \pm 0 \cdot 3$ \\
$95: 5$ & $9 \cdot 0$ & $0 \cdot 3 \pm 0 \cdot 2$ \\
$90: 10$ & $30 \cdot 2$ & $2 \cdot 8 \pm 0 \cdot 6$ \\
$80: 20$ & $9 \cdot 1$ & $0 \cdot 8 \pm 0 \cdot 2$ \\
$70: 30$ & $2 \cdot 8$ & $0 \cdot 8 \pm 0 \cdot 4$ \\
$60: 40$ & $3 \cdot 5$ & $0 \cdot 5 \pm 0 \cdot 4$ \\
$\mathrm{MeOH}$ & $15 \cdot 5$ & $0 \cdot 3 \pm 0 \cdot 2$ \\
No sample & & $0 \cdot 2 \pm 0 \cdot 2$ \\
\hline
\end{tabular}

* [Eluted amounts (dry wt) in each fraction divided by applied chloroform/methanol phase $(50 \mathrm{mg})] \times 100$.

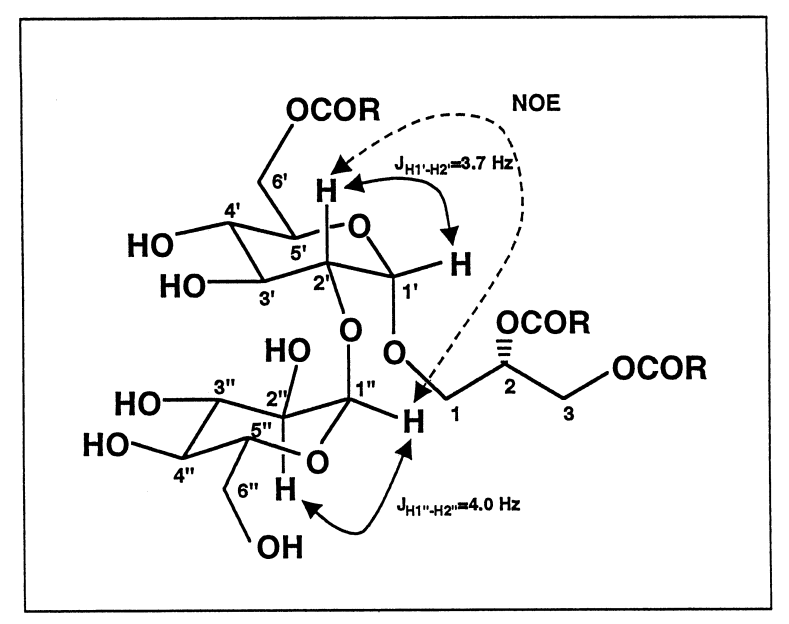

Fig. 1. Chemical structure of glycoglycerolipid isolated from membranes of $A$. laidlawii.

nostics) as described previously (Arai et al., 1983). Five million cells $\mathrm{ml}^{-1}$ were incubated in a Petri dish at $37^{\circ} \mathrm{C}$ for $1 \mathrm{~h}$ to remove adherent cells. Nonadherent cells were collected and incubated with M-450 CD4 Dynabeads (Dynal) for $3 \mathrm{~h}$ at $37^{\circ} \mathrm{C}$, and $\mathrm{CD} 4^{+}$cells were then collected according to the manufacturer's instructions. The purified $\mathrm{CD}^{+}$cells were cultured in RPMI1640 with $12 \%$ FCS, 100 units human recombinant interleukin-2 (Becton Dickinson Labware) $\mathrm{ml}^{-1}$ and 100 units of human recombinant interleukin-4 (Genzyme Diagnostics) $\mathrm{ml}^{-1}$ in a 24 -well cell culture plate (Costar) coated with anti-human CD3 antibody (Serotec).

Cell binding assay. Extracts from the membranes of $A$. laidlawii and synthetic 3-O-[2'-O-( $\alpha$-D-glucopyranosyl)$6^{\prime}$-O-acyl- $\alpha$-D-glucopyranosyl]-1,2-di-O-acyl-sn-glycerols (GAGDGs) were dissolved in chloroform and $50 \mu \mathrm{l}$ samples were spread on individual $10 \mathrm{~mm}$ diameter coverglasses (Matsunami) to make thin films of GAGDGs. To avoid nonspecific adherence of cells, each coverglass was immersed in RPMI/FCS medium. After $1 \mathrm{~h}$, the medium was removed by suction and replaced with serum-free tissue culture medium (Cosmo medium ; Cosmo Bio). Cells were suspended in Cosmo medium at a concentration of $4 \times 10^{5}$ cells $\mathrm{ml}^{-1}$ and $0.5 \mathrm{ml}$ of the suspension was added to each well of a 24 -well cell culture plate with a GAGDG-coated coverglass. The plate was then incubated at $37^{\circ} \mathrm{C}$ in a $\mathrm{CO}_{2}$ incubator for $4 \mathrm{~h}$. The coverglass was then removed with forceps and gently dipped twice in warmed PBS (137 mM NaCl, $2.68 \mathrm{mM} \mathrm{KCl,} 1.47 \mathrm{mM}$ $\left.\mathrm{KH}_{2} \mathrm{PO}_{4}, 8.1 \mathrm{mM} \mathrm{Na} \mathrm{HPO}_{4}\right)$. The adherent cells on the coverglass were scraped off with a rubber policeman. The cell suspensions from five coverglasses were centrifuged at $170 \mathrm{~g}$ for $5 \mathrm{~min}$ and the cells were resuspended in $0.2 \mathrm{ml} \mathrm{RPMI} / \mathrm{FCS}$. The cells were counted with a haemocytometer. For detection of adherence to A. laidlawii, $0 \cdot 1 \mathrm{ml}$ of a $1 \times 10^{7}$ c.f.u. $\mathrm{ml}^{-1}$ suspension of A. laidlawii was inoculated into each well of a cell culture plate and incubated in $1 \mathrm{ml} \mathrm{RPMI} / \mathrm{FCS}$ medium for $3 \mathrm{~d}$ at $37^{\circ} \mathrm{C}$ in a $\mathrm{CO}_{2}$ incubator. The medium was then removed and suspensions of eukaryotic cells in Cosmo medium were added to different wells. The adherent cells were counted as described above. An alternative method for estimation of cell numbers was also employed. Briefly, after removing nonadherent cells, residual cells on the coverglasses were incubated for $4 \mathrm{~h}$ at $37^{\circ} \mathrm{C}$ in a $\mathrm{CO}_{2}$ incubator in the presence of $1 \mu \mathrm{Ci}(37 \mathrm{kBq})\left[6-{ }^{3} \mathrm{H}\right]$ thymidine [specific activity $16 \cdot 3 \mathrm{Ci}(603 \mathrm{GBq}) \mathrm{mmol}^{-1}$; Dupont NEN]. The cells were lysed, DNA was precipitated onto glass filters and the amount of $\left[6-{ }^{3} \mathrm{H}\right]$ thymidine incorporation was determined. Both methods for estimation of numbers of binding cells were used in five independent experiments.

Fractionation of $\boldsymbol{A}$. laidlawii membranes. Membranes of $A$. laidlawii PG8 ATCC 23206 were isolated by osmotic lysis as described previously (Iyama et al., 1996). The membranes of A. laidlawii were extracted twice using the Bligh-Dyer method with 40 vols water/chloroform/methanol $(0 \cdot 8: 2: 1$, by vol.). Extracted lipids were dried on a rotary evaporator. Fifty milligrams of the lipid was resuspended in chloroform for application to a column of $10 \mathrm{~g}$ activated silica gel (Silica gel 60; Merck) prepared in chloroform. Sequential elution of the lipids from the column was performed with a discontinuous gradient starting with $400 \mathrm{ml}$ of chloroform and followed by $400 \mathrm{ml}$ each of the following mixtures of chloroform/ methanol $(\mathrm{v} / \mathrm{v}): 95: 5,90: 10,80: 20,70: 30,60: 40$, and finally $400 \mathrm{ml}$ methanol. The fraction showing binding activity was further purified by TLC (Silica gel $60,1 \cdot 2 \mathrm{~mm}$ in thickness) using chloroform/methanol/acetic acid (85:15:0.5, by vol.).

Structure determination by NMR and GC-MS. The structure of a component of the membranes of A. laidlawii with binding activity was determined by ${ }^{13} \mathrm{C}-\mathrm{NMR},{ }^{1} \mathrm{H}-\mathrm{NMR}$ and $\mathrm{GC}-$ MS analysis. Detailed one- and two-dimensional NMR studies of lipid X $\left\{[\alpha]_{\mathrm{D}}^{28}+39^{\circ} \mathrm{C}\left(\mathrm{c} 0 \cdot 1, \mathrm{CHCl}_{3}\right)\right\}$ by ${ }^{1} \mathrm{H}-{ }^{1} \mathrm{H}$ DQFCOSY, HOHAHA $\left(\tau_{\mathrm{m}}=60 \mathrm{~ms}\right)$ and HMQC experiments with a JEOL $\alpha-500$ spectrometer in $\mathrm{CHCl}_{3}-\mathrm{CH}_{3} \mathrm{OD}(1: 1, \mathrm{v} / \mathrm{v})$ allowed sequential assignments of proton and carbon resonances. Molecular ion peaks of the fatty acid methyl esters from lipid X by GC-MS indicated that the fatty acyl groups of the lipid were a mixture of straight- and branched-chain fatty acids. The lipids $(0.7 \mathrm{mg}$ in $0.5 \mathrm{ml}$ methanol) were treated with $15 \mu \mathrm{l} 140 \mathrm{mM}$ sodium methoxide in methanol and the resulting fatty acid methyl esters were analysed by GC-MS equipped with a $25 \mathrm{~m}$ PEGM capillary column and electron ionizationMS spectrometry (Huang \& Anderson, 1995). 

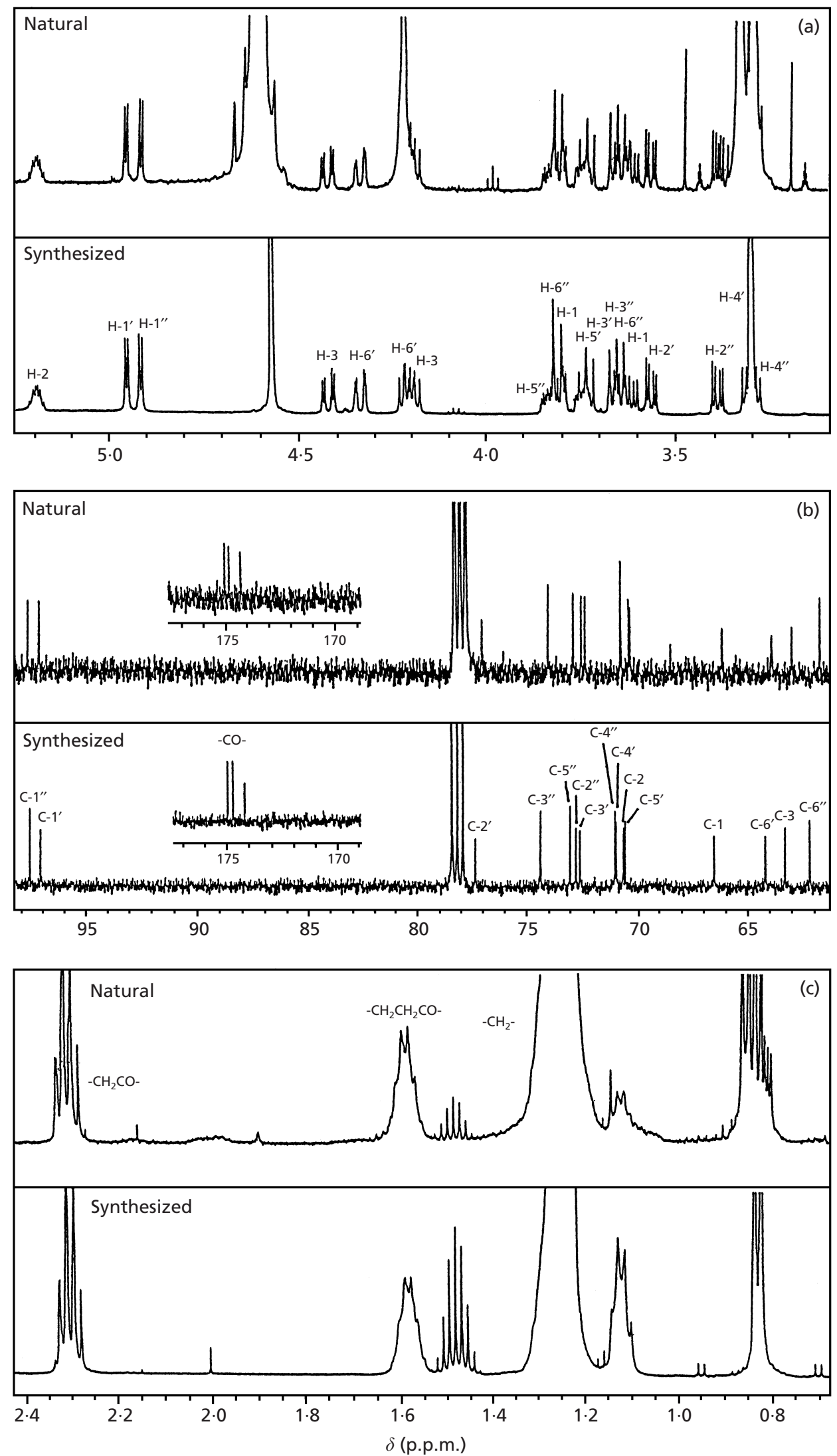

Fig. 2. Assignments for the compounds obtained by TLC (natural) and their synthetic analogues (synthesized). (a, c) ${ }^{1} \mathrm{H}-\mathrm{NMR}, 500 \mathrm{MHz}$; (b) ${ }^{13} \mathrm{C}-\mathrm{NMR}, 125 \mathrm{MHz}$. 
Synthesis of GAGDGs. Synthesis of glycoglycerolipids essentially followed a method established by van Boeckel \& van Boom (1985a, b, c).

\section{RESULTS}

\section{Purification of the active component from A. laidlawii membranes}

The adherence of MOLT-4 cells to coverglasses bearing colonies of $A$. laidlawii or glycolipids extracted from $A$. laidlawii using the Bligh-Dyer method was tested. The number of adherent cells was determined by both direct counting of cell numbers and $\left[6{ }^{3} \mathrm{H}\right]$ thymidine incorporation by adherent cells. The numbers of cells binding in the presence of $A$. laidlawii, their membranes, the chloroform/methanol phase, the water/methanol phase and in the negative control were $1.5 \pm 0.9 \times 10^{4}$, $1 \cdot 3 \pm 0 \cdot 1 \times 10^{4}, 4 \cdot 5 \pm 0.5 \times 10^{4}, 0 \cdot 3 \pm 0 \cdot 1 \times 10^{4}$ and less than $0 \cdot 1 \times 10^{4}$ per coverglass, respectively. The amounts of $\left[6-{ }^{3} \mathrm{H}\right]$ thymidine incorporated by adherent cells in the presence of these fractions, were $2.5 \pm 0 \cdot 07 \times 10^{4}$, $2 \cdot 8 \pm 0.05 \times 10^{4}, 12 \cdot 9 \pm 0 \cdot 09 \times 10^{4}, 0 \cdot 8 \pm 0 \cdot 01 \times 10^{4}$ and $0.08 \pm 0.03 \times 10^{4}$ c.p.m., respectively. These results indicated that the binding activity was in the chloroform/ methanol phase, but not in the water/methanol phase. Further purification of the active component in the chloroform/methanol phase was performed using silica gel column chromatography. As shown in Table 1, binding activity was clearly demonstrated in the fraction eluted with chloroform/methanol $(90: 10, \mathrm{v} / \mathrm{v})$, but not in the other six fractions. The component showing the binding activity was further purified by TLC. Two spots of $R_{\mathrm{F}} 0.36$ and $R_{\mathrm{F}} 0.64$ were separated by development with chloroform/methanol/acetic acid $(85: 15: 0 \cdot 5$, by vol.). Both spots were scraped off and eluted with chloroform/methanol $(1: 1, \mathrm{v} / \mathrm{v})$. The activity was clearly found in the spot with $R_{\mathrm{F}} 0 \cdot 36$.

\section{Chemical structure of active natural components and their synthetic compounds}

The chemical structure of the active component separated by TLC was determined by ${ }^{1} \mathrm{H}-\mathrm{NMR},{ }^{13} \mathrm{C}-$ NMR and GC-MS. The chemical structure of synthetic compounds was also examined. As shown in Figs 1 and $2(\mathrm{a})$, the two glucose units were readily assigned by sequential large axial-axial couplings for the pyranose methine protons of $\mathrm{H}^{\prime}$ to $\mathrm{H}^{\prime}{ }^{\prime}(3.58,3.74,3.31$, 3.75 p.p.m.) and $\mathrm{H} 2^{\prime \prime}$ to $\mathrm{H}^{\prime \prime}$ (3.40, 3.67, 3.29, 3.85 p.p.m.). Five spin systems for the glycerol protons were also easily recognized (Fig. 2a). HMQC spectra clearly showed ${ }^{13} \mathrm{C}$ assignments for the glucosyl and glycerol units, C-1 to C-3 $\left(66 \cdot 6,70 \cdot 8,63 \cdot 5\right.$ p.p.m., C- $1^{\prime}$ to C-6' $(97 \cdot 2,77 \cdot 4,72 \cdot 6$, overlapped with methanol peak, $70 \cdot 7,64 \cdot 4$ p.p.m.) and C- $1^{\prime \prime}$ to C-6" (97.7, 72.8, 74.3, overlapped with methanol peak, $73 \cdot 2,62 \cdot 2$ p.p.m.) (Fig. 2b). Also, ${ }^{1} \mathrm{H}$ resonance at $0 \cdot 79-0 \cdot 86(\mathrm{~m}, \mathrm{Me}), 1 \cdot 17-1 \cdot 31$ (m, methylene), $1.54-1.62\left(6 \mathrm{H}, \mathrm{m}, \mathrm{CH}_{2} \mathrm{CH}_{2} \mathrm{CO}\right)$ and 2.27-2.34 p.p.m. (6H, m, $\mathrm{CH}_{2} \mathrm{CO}$ ) (Fig. 2c) and ${ }^{13} \mathrm{C}$
Table 2. Fatty acid composition of the lipid side chain as determined by GC-MS

\begin{tabular}{|c|c|c|}
\hline $\begin{array}{l}\text { Retention } \\
\text { time in GC } \\
(\min )\end{array}$ & $\begin{array}{c}\text { Proportion } \\
(\%)\end{array}$ & $\begin{array}{c}\text { Assignment } \\
\text { (fatty acid } \\
\text { methyl esters) }\end{array}$ \\
\hline $11 \cdot 05$ & $0 \cdot 4$ & NA \\
\hline $12 \cdot 2$ & $4 \cdot 6$ & $\mathrm{nC}_{12}$ \\
\hline $14 \cdot 6$ & $5 \cdot 6$ & isoC $_{13}$ \\
\hline $15 \cdot 0$ & $1 \cdot 3$ & $\mathrm{NA}$ \\
\hline $19 \cdot 7$ & $10 \cdot 7$ & iso $_{14}$ \\
\hline $21 \cdot 4$ & $17 \cdot 8$ & $\mathrm{nC}_{14}$ \\
\hline $23 \cdot 8$ & $4 \cdot 2$ & isoC $_{15}$ \\
\hline $24 \cdot 1$ & $8 \cdot 4$ & $\mathrm{C}_{15} \dagger$ \\
\hline $25 \cdot 0$ & $1 \cdot 3$ & $\mathrm{nC}_{15}$ \\
\hline $25 \cdot 2$ & $0 \cdot 5$ & NA \\
\hline $26 \cdot 8$ & $1 \cdot 4$ & isoC $_{16}$ \\
\hline $27 \cdot 9$ & $34 \cdot 9$ & $\mathrm{nC}_{16}^{10}$ \\
\hline $29 \cdot 4$ & 0.7 & iso $_{17}$ \\
\hline $29 \cdot 7$ & $0 \cdot 4$ & NA \\
\hline $30 \cdot 3$ & $0 \cdot 4$ & $\mathrm{nC}_{17}$ \\
\hline $31 \cdot 3$ & $0 \cdot 7$ & NA \\
\hline $32 \cdot 2$ & $2 \cdot 3$ & $\mathrm{nC}_{18}$ \\
\hline $32 \cdot 5$ & $4 \cdot 3$ & NA \\
\hline
\end{tabular}

NA, Not assigned.

* $\mathrm{nC}_{\mathrm{m}}, \quad \mathrm{nCH}_{3}\left(\mathrm{CH}_{2}\right)_{\mathrm{m}} 2 \mathrm{CO}_{2} \mathrm{CH}_{3} ; \quad$ isoC $\mathrm{m}, \quad\left(\mathrm{CH}_{3}\right) 2 \mathrm{CH}\left(\mathrm{CH}_{2}\right)_{\mathrm{m}}$ $4 \mathrm{CO}_{2} \mathrm{CH}_{3}$.

† Structure not known.

resonance at $174 \cdot 3,174 \cdot 8$ and $175 \cdot 0$ p.p.m. (Fig. 2b) indicated three fatty acids attached to the diglucosyl glycerol. Downfield shift of the five proton resonance at H-2 (5.18-5.23 p.p.m.) and H-3 (4.21, 4.35 p.p.m.) of the glycerol moiety as well as the hydroxymethyl resonance H-6' (4.21, 4.35 p.p.m.) of one glucosyl unit implied that the three acyl groups were located on the C-2, C-3 and C-6 hydroxyl groups. A ROESY spectrum $\left(\tau_{\mathrm{m}}=\right.$ $200 \mathrm{~ms}$ ) showed a signal cross peak between the two sugar moieties [H-2' (3.76 p.p.m.) and H-1" (4.92 p.p.m.)]. The coupling constant of the anomeric proton $\mathrm{H}-1^{\prime \prime}$ was $4.0 \mathrm{~Hz}$. These observations indicated that the two glucosyl units had an $\alpha$-glycoside linkage between $\mathrm{C}-2^{\prime}$ and $\mathrm{C}-1^{\prime \prime}$. Another anomeric proton $\mathrm{H}-1^{\prime}$ (4.96 p.p.m.) also showed a small coupling constant $(3.7 \mathrm{~Hz})$. Therefore, the anomeric carbon $\left(\mathrm{C}-1^{\prime}\right)$ also had an $\alpha$-linkage. The structure of the lipid was determined as 3-O-[2'-O-( $\alpha$-D-glucopyranosyl $)-6^{\prime}-O-\alpha-$ D-glucopyranosyl-1,2-di-O-acyl-sn-glycerol (GAGDG, Fig. 1). The spectra of the natural compound were identical to the spectra of the synthetic compound except for that for the acyl groups. As shown in Table 2, the compositions of the major saturated fatty acids $\mathrm{nC}_{14}$, iso $\mathrm{C}_{14}, \mathrm{nC}_{16}$ were $17 \cdot 8,10.7$ and $34.9 \%$, respectively, as determined by GC-MS. The amounts of the unsaturated species were less than $10 \%$ of those of the corresponding saturated acids. 

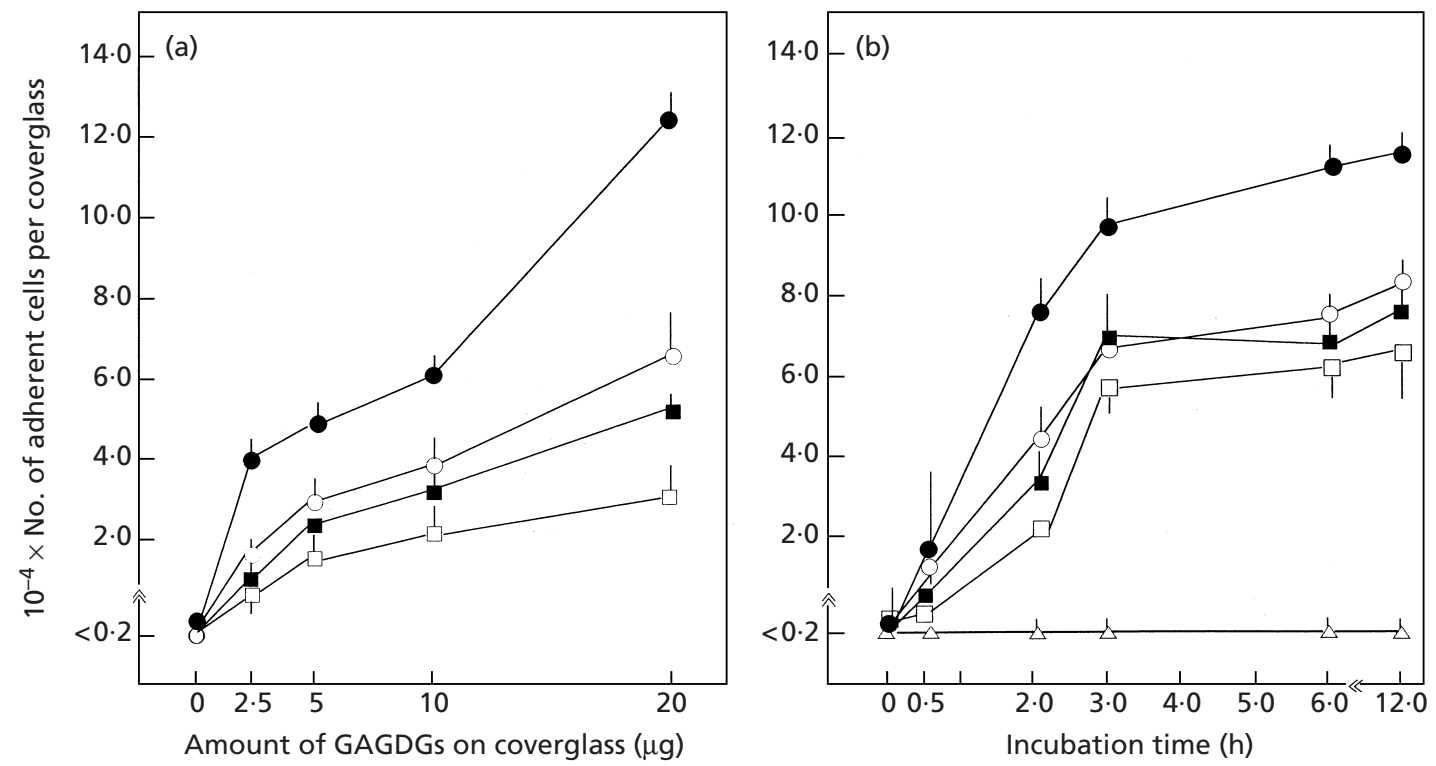

Fig. 3. (a) Effect of GAGDG concentration on binding to MOLT-4 cells. Cells $\left(20 \times 10^{4}\right)$ were incubated in a culture plate in the presence of a coverglass with synthetic GAGDGs containing isoC ${ }_{14}(0), \mathrm{nC}_{14}(\bigcirc)$ or $\mathrm{nC}_{16}(\square)$, or GAGDGs of $A$. laidlawii membranes ( $\boldsymbol{\square}$ ) for $4 \mathrm{~h}$ at $37^{\circ} \mathrm{C}$. Values shown are means + SD of five assays. (b) Cell attachment over time. MOLT-4 cells $\left(20 \times 10^{4} \mathrm{ml}^{-1}\right)$ were incubated in a culture plate in the presence of a coverglass coated with $10 \mu \mathrm{g}$ of synthetic GAGDGs containing isoC ${ }_{14}(\bullet), \mathrm{nC}_{14}(\bigcirc)$ or $\mathrm{nC}_{16}(\square)$, GAGDGs of A. laidlawii membranes ( $\square$ ) or an uncoated control $(\triangle)$. Values shown are means + SD of five assays from one representative experiment.

Table 3. Binding of GAGDGs to various lymphoid cells

Various cell lines $\left(2 \times 10^{5}\right.$ cells) were incubated in the presence of coverglasses with 20 or $10 \mu \mathrm{g}$ of the natural GAGDGs of $A$. laidlawii and synthetic GAGDGs at $37^{\circ} \mathrm{C}$ for $4 \mathrm{~h}$ in a $\mathrm{CO}_{2}$ incubator. Values shown $\left(10^{-4} \times\right.$ no. of adherent cells per coverglass $)$ are means \pm SD of five assays from one representative experiment.

\begin{tabular}{|c|c|c|c|c|c|c|c|}
\hline \multirow[t]{3}{*}{ Cell line } & \multicolumn{2}{|c|}{ GAGDG of $A$. laidlawii } & \multicolumn{4}{|c|}{ Synthetic GAGDGs } & \multirow[t]{3}{*}{ None } \\
\hline & \multirow[b]{2}{*}{$20 \mu \mathrm{g}$} & \multirow[b]{2}{*}{$10 \mu \mathrm{g}$} & \multicolumn{2}{|c|}{ isoC $_{14}$} & \multicolumn{2}{|c|}{$\mathrm{nC}_{16}$} & \\
\hline & & & $20 \mu \mathrm{g}$ & $10 \mu \mathrm{g}$ & $20 \mu \mathrm{g}$ & $10 \mu \mathrm{g}$ & \\
\hline Raji & $28 \cdot 0 \pm 2 \cdot 7$ & $18 \cdot 7 \pm 2 \cdot 0$ & $27 \cdot 5 \pm 3 \cdot 0$ & $16 \cdot 7 \pm 3 \cdot 1$ & $15 \cdot 0 \pm 1 \cdot 2$ & $5 \cdot 6 \pm 2 \cdot 0$ & $0 \cdot 9 \pm 0 \cdot 5$ \\
\hline HL-60 & $24 \cdot 7 \pm 2 \cdot 5$ & $15 \cdot 3 \pm 1 \cdot 8$ & $29 \cdot 6 \pm 3 \cdot 0$ & $12 \cdot 4 \pm 2 \cdot 5$ & $13 \cdot 8 \pm 2 \cdot 0$ & $8 \cdot 5 \pm 1 \cdot 5$ & $0 \cdot 2 \pm 0 \cdot 2$ \\
\hline MOLT-4 & $6 \cdot 4 \pm 1 \cdot 4$ & $4 \cdot 5 \pm 0.7$ & $26 \cdot 0 \pm 4 \cdot 0$ & $16 \cdot 3 \pm 1 \cdot 8$ & $8 \cdot 3 \pm 2 \cdot 2$ & $5 \cdot 2 \pm 1 \cdot 2$ & $0 \cdot 1 \pm 0 \cdot 3$ \\
\hline HUT-78 & $12 \cdot 5 \pm 1 \cdot 8$ & $2 \cdot 8 \pm 0 \cdot 2$ & $22 \cdot 4 \pm 1 \cdot 8$ & $14 \cdot 2 \pm 2 \cdot 0$ & $5 \cdot 3 \pm 0 \cdot 8$ & $3 \cdot 5 \pm 1 \cdot 0$ & $0 \cdot 2 \pm 0 \cdot 8$ \\
\hline $\mathrm{CD}^{+}{ }^{+}$cells* & $5 \cdot 0 \pm 0 \cdot 6$ & $3 \cdot 0 \pm 0 \cdot 4$ & $15 \cdot 3 \pm 4 \cdot 0$ & $10 \cdot 5 \pm 1 \cdot 5$ & $8 \cdot 2 \pm 0 \cdot 4$ & $3 \cdot 7 \pm 1 \cdot 0$ & $0 \cdot 1 \pm 0 \cdot 1$ \\
\hline
\end{tabular}

*CD4 ${ }^{+}$cells purified using magnetic beads were cultured in the presence of $100 \mathrm{U}$ IL-2 and IL-4 ml ${ }^{-1}$.

\section{The binding activity of synthetic GAGDGs}

As shown in Fig. 3(a), the number of adherent cells was directly related to the concentration of GAGDGs. However, GAGDGs with $\mathrm{nC}_{14}$ and $\mathrm{nC}_{16}$ had a lower binding activity compared with those with iso $\mathrm{C}_{14}$. As shown in Fig. 3(b), the adherence of cells began within $30 \mathrm{~min}$ and reached a maximum at $6 \mathrm{~h}$.

Adherent cells were not observed in the absence of GAGDG. Table 3 shows one set of representative results from five experiments on the adherence of various cells to GAGDGs. The number of adherent cells was highest for Raji cells, but the difference between the other types of cells was not significant.

\section{DISCUSSION}

In this study we have shown that glycoglycerolipids obtained from A. laidlawii membranes and synthetic glycoglycerolipids bind to both human lymphoid cell lines and human peripheral $\mathrm{T}$ cells. Our results provide new information on the interaction between glyco- 
glycerolipids of prokaryotic cell membranes and eukaryotic cells.

Glycoglycerolipids are not only found in the cell membranes of mycoplasmas, but also in those of Gramnegative and Gram-positive bacteria, and their L-forms (Kates, 1990). However, their function in the membranes of prokaryotic cells is not clear. Several investigators have reported that glycolipids in the membranes of $A$. laidlawii are mono- and di-glycosyldiacylglycerol (Bhakoo et al., 1987; Dahlqvist et al., 1995; Gross \& Rottem, 1979; Shaw 1968) and that they might play an important role in physiological functions such as membrane viscosity (De Kruyft et al., 1973; McElhaney et al., 1970; McElhaney, 1975; Rottem et al., 1973). Several reports suggest that the fusion of mycoplasmas with eukaryotic cells may result in the delivery of mycoplasma components into the host cells (Toole \& Lowdell, 1990; Franzoso et al., 1992). Furthermore, Rottem (1980) reported that the presence of cholesterol in small unilamellar vesicles is required to allow their fusion with mycoplasmas. These findings suggest that GAGDGs, a major component of A. laidlawii membranes (Shaw, 1970; Silvius et al., 1980), might play an important role not only in the membrane fluidity of prokaryotic cells, but also in interactions between micro-organisms lacking cell walls and eukaryotic cells.

Our results strongly suggest that glycoglycerolipids in $A$. laidlawii membranes might participate in the adhesion of bacterial cells to eukaryotic cells. The role of glycoglycerolipids in the pathogenesis of A. laidlawii infections is unknown. The induction of conformational changes in the membranes of eukaryotic cells as well as in those of prokaryotic cells by glycoglycerolipids may be responsible for these biological activities. In this study, we have clearly demonstrated that glycoglycerolipids possess the ability to bind to certain kinds of eukaryotic cells. However, we need to clarify the initial binding sites and the significance of this phenomenon in infections.

\section{REFERENCES}

Allan, E. J., Amijee, F., Tyson, R. H., Strang, J. A., Innes, C. M. \& Paton, A. M. (1993). Growth and physiological characteristics of Bacillus subtilis L-form. J Appl Bacteriol 74, 588-594.

Arai, S., Yamamoto, H., Ito, K. \& Kumagai, K. (1983). Suppressive effect of human natural killer cells on pokeweed mitogen induced B cell differentiation. J Immunol 131, 651-657.

Bhakoo, M., Lewis, R. N. A. H. \& McElhaney, R. N. (1987). Isolation and characterization of a novel monoacylated glucopyranosyl neutral lipid from the plasma membrane of Acholeplasma laidlawii B. Biochim Biophys Acta 922, 34-45.

van Boeckel, C. A. A. \& van Boom, J. H. (1985a). Synthesis of phosphatidyl- $\alpha$-glucosyl glycerol containing a dioleoyl phosphatidyl moiety. Application of the tetraisopropyldisiloxane-1,3-diyl (tips) protecting group in sugar chemistry, part III. Tetrahedron 41, 4545-4555.

van Boeckel, C. A. A. \& van Boom, J. H. (1985b). Synthesis of phosphatidyl- $\beta$-glucosyl glycerol containing a dioleoyl diglyceride moiety. Application of the tetraisopropyldisiloxane-1,3-diyl (tips) protecting group in sugar chemistry, part IV. Tetrabedron 41, $4557-4565$.

van Boeckel, C. A. A. \& van Boom, J. H. (1985c). Synthesis of streptococci phosphatidyl- $\alpha$-diglucosyldiglyceride and related glycolipids. Application of the tetraisopropyldisiloxane-1,3-diyl (tips) protecting group in sugar chemistry, part V. Tetrahedron 41, 4567-4575.

Boggs, I. M. (1987). Lipid intermolecular hydrogen bonding; influence on structural organization and membrane function. Biochim Biophys Acta 906, 353-404.

Courtney, H. S., Ofek, I., Simpson, W. A., Hasty, D. L. \& Beachey, E. H. (1986). Binding of Streptococcus pyogenes to soluble and insoluble fibronectin. Infect Immun 53, 454-459.

Dahlqvist, A., Nordstrom, S., Karlsson, O. P., Mannock, D. A., McElhaney, R. N. \& Wieslander, Å. (1995). Efficient modulation of glucolipid enzyme activities in membranes of Acholeplasma laidlawii by the type of lipids in the bilayer matrix. Biochemistry 34, 13381-13389.

De Kruyft, B., van Dijck, P. W. M., Goldbach, R. W., Demel, R. A. \& van Deenen, L. L. M. (1973). Influence of fatty acid and sterol composition on the lipid phase transition and activity of membrane-bound enzymes in Acholeplasma laidlawii. Biochim Biophys Acta 330, 269-282.

Elleman, T. C., Hoyne, P. A., Emery, D. L., Stewart, D. J. \& Clark, B. L. (1986). Expression of the pilin gene from Bacteroides nodosus in Escherichia coli. Infect Immun 51, 187-192.

Espersen, F. \& Clemmensen, I. (1982). Isolation of a fibronectinbinding protein from Staphylococcus aureus. Infect Immun 37, 526-531.

Franzoso, G., Dimitrov, D. S., Blumenthal, R., Barile, M. F. \& Rottem, S. (1992). Fusion of Mycoplasma fermentans strain incognitus with T lymphocytes. FEBS Lett 303, 251-254.

Gross, Z. \& Rottem, S. (1979). Lipid distribution in Acholeplasma laidlawii membrane. A study using the lactoperoxidase-mediated iodination. Biochim Biophys Acta 555, 547-552.

van Houte, J. (1983). Bacterial adherence in the mouth. Rev Infect Dis 5, s659-s669.

Huang, Y. \& Anderson, R. (1995). Glucosyl diglyceride lipid structures in Deinococcus radiodurans. J Bacteriol 177, 2567-2571.

lyama, K., Ono, S., Kuwano, K., Ohishi, M., Shigematsu, H. \& Arai, S. (1996). Induction of tumour necrosis factor alpha $(\mathrm{TNF} \alpha)$ and enhancement of HIV-1 replication in the J22HL60 cell line by Mycoplasma penetrans. Microbiol Immunol 40, 907-914.

Kates, M. (1990). Glyco-, phosphoglyco-, and sulfoglycoglycerolipids of bacteria. In Handbook of Lipid Research, vol. 6, Glycolipids, Phosphoglycolipids, and Sulfoglycolipids, pp. 1-123. Edited by M. Kates. New York \& London: Plenum.

McElhaney, R. N. (1975). Membrane lipid, not polarized water, is responsible for the semipermeable properties of living cells. Biophys J 15, 777-784.

McElhaney, R. N., de Gier, J. \& van Deenen, L. L. M. (1970). The effect of alterations in fatty acid composition and cholesterol content on the permeability of Mycoplasma laidlawiii B cells and derived liposomes. Biochim Biophys Acta 219, 245-247.

Rottem, S. (1980). Membrane lipids of mycoplasmas. Biochim Biophys Acta 604, 65-90.

Rottem, S., Cirillo, V. P., de Kruyff, B., Shinitzky, M. \& Razin, S. (1973). Cholesterol in mycoplasma membranes. Correlation of enzymic and transport activities with physical state of lipids in membranes of Mycoplasma mycoides var. capri adapted to grow 
with low cholesterol concentrations. Biochim Biophys Acta 323, 509-519.

Shaw, N. (1968). The lipid composition of Mycoplasma laidlawii strain B. Biochem J 107, 329-333.

Shaw, N. (1970). Bacterial glycolipids. Bacteriol Rev 34, 365-377. Silvius, J. R., Mak, N. \& McElhaney, R. N. (1980). Lipid and protein composition and thermotropic lipid phase transitions in fatty acid homogeneous membranes of Acholeplasma laidlawii B. Biochim Biophys Acta 597, 199-215.

Toole, C. O. \& Lowdell, M. (1990). Infection of human T cells with mycoplasma, inhibition of CD4 expression and HIV-1 gp120 glycoprotein binding, and infectivity. Lancet 336, 1067.

Received 7 January 2000; revised 10 May 2000; accepted 23 May 2000. 